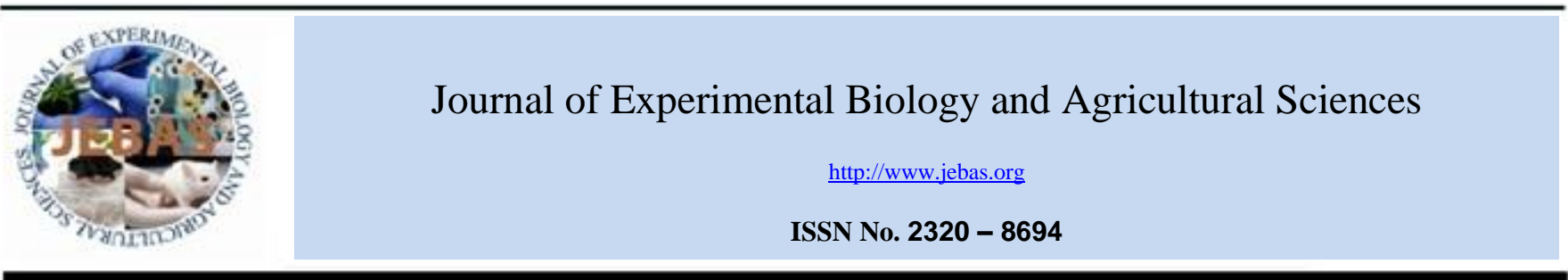

\title{
FEATURES OF THE SEASONAL DYNAMICS OF PHYTOPLANKTON AT THE LEFT BANK OF THE VOLGA REACH OF KUIBYSHEV RESERVOIR (REPUBLIC OF TATARSTAN, RF)
}

\section{Liliya Yunusovna Khaliullina}

Associate Professor, Department of Botany and Plant Physiology, Institute of Fundamental Medicine and Biology, Kazan Federal University, Kazan, Russia Id scopus: http://www.scopus.com/authid/detail.url?authorId=30467858200

Received - September 25, 2020; Revision - November 12, 2020; Accepted - December 15, 2020

Available Online December 15, 2020

DOI: http://dx.doi.org/ 10.18006/2020.8(Spl-2-AABAS).S272.S279

\section{KEYWORDS \\ Algocenosis \\ Phytoplankton \\ Algae \\ River Volga \\ Kuibyshev Reservoir}

\begin{abstract}
Biocenosis of shallow waters of lowland reservoirs lives in various habitat regimes and are characterized by a special structural and functional organization. To fully elucidate these features, it is necessary to research several hydrologically different areas simultaneously. This study was conducted to evaluate the effect of seasonal dynamics on the phytoplankton community of the Volga reach of the Kuibyshev reservoir near the left bank. During the observation period, 112 taxa were found in the phytoplankton of the studied site. The greatest number of taxa were identified from the groups of diatoms $(44 \%)$ and green (28\%) algae. Some other less diverse groups are blue-green (16\%), Chrysophyta (6\%), cryptophyta and dinophyta (3\%), etc. Cosmopolitan and planktonic species of algae prevail in terms of environmentally-geographical characteristics. Concerning halobility, most species are indifferent, and in terms of $\mathrm{pH}$, the most common are the indifferent alkaliphile + alkalibiontic algae. The total abundance and biomass of planktonic algae range 8.49-1661.09 mln.cl./l and $10.28-114.11 \mathrm{mg} / \mathrm{l}$ respectively. Some important dominant species are blue-green algae Microcystis aeruginosa f. flos-aquae, Aphanizomenon flos-aquae, Anabaena flos-aquae, Anabaena scheremetievi, Aulacoseira italica, Navicula sp., Carteria globosa, Chlamydomonas sp., Pandorina morum, Scenedesmus guadricauda. Seasonal dynamics of phytoplankton have two peaks of abundance and biomass which are at the end of the first decade of July and in the second decade of August. Both maxima are due to the massive development of blue-green algae, which causes water to "bloom". The phytoplankton of the investigated section of the Kuibyshev reservoir is dominated by $\beta$-mesosaprobic organisms.
\end{abstract}

* Corresponding author

E-mail: Liliya-kh@yandex.ru (Liliya Yunusovna Khaliullina)

Peer review under responsibility of Journal of Experimental Biology and Agricultural Sciences.

Production and Hosting by Horizon Publisher India [HPI] (http://www.horizonpublisherindia.in/).

All rights reserved.
All the articles published by Journal of Experimental Biology and Agricultural Sciences are licensed under a Creative Commons Attribution-NonCommercial 4.0 International License Based on a work at www.jebas.org.

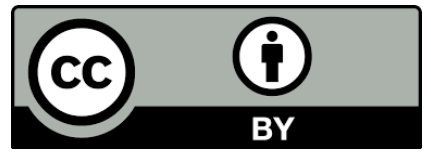




\section{Introduction}

Kuibyshev reservoir is the sixth step of the Volga cascade, that was filled in 1955-1957 after damming out the river Volga near the Zhiguli Mountains (Russia, Republic of Tatarstan) (Kuibyshev reservoir, 2008; Kuibyshev reservoir phytoplankton ecology, 1989). Among all the reservoirs created on the river valleys, this reservoir ranked first in Europe and second in the world. The right and left banks of the Kuibyshev reservoir are different, among these two, the left bank is mostly flat and low while the right bank is high and steep. As we know, in the northern hemisphere, the right bank of the rivers is always higher and steeper, prone to collapse, and the left bank is flat and low-lying, prone to flooding during floods. This rule is known as "Baer's Law", is also valid for the rivers of the Northern Hemisphere, flowing from north to south (Stasenko, 1997). Rivers wash away their right bank, leaving sand and sediment on the left. You can see that the same law is opposite for the rivers of the southern hemisphere - a steep left bank and a flat right bank. The law was formulated in 1857 by K.M. Baer and is explained by the joint action of the Coriolis force and the friction force, which creates a rotational motion of the masses of water around the axis of the channel, which causes the transfer of matter between the banks. As a result of this circumstance, the conditions for the existence of aquatic organisms vary greatly (Korneva, 2009; Khaliullina et al., 2009). This is primarily because most of the left bank of the Volga River and the Kuibyshev reservoir have a shallow water. The distribution of phytoplankton with this aspect remains poorly understood in the Kuibyshev reservoir. The objective of this study was to identify the features of the seasonal dynamics of phytoplankton in the Volga reach of the Kuibyshev reservoir near the left bank.

\section{Materials and Methods}

From June to September 2015, a weekly sampling of phytoplankton was carried out at the Kuibyshev reservoir (the Volga river) in an open water area. The layout of the study area is shown in Figure 1. Phytoplankton samples were collected from a depth of $0.5-1.5 \mathrm{~m}$. During the study period, a total of 26 quantitative and qualitative samples were collected.

The selection and processing of the collected phytoplankton samples were carried out according to standard methods (Algae, 1989; Krammer, 1991a; Krammer, 1991b; AlgaBase, 2000; Sadchikov, 2003; Pröschold\&Leliaert, 2007; Cantonati, 2017). For this, all quantitative samples of $0.5 \mathrm{~L}$ were fixed with $40 \%$ formalin solution. The fixed samples were concentrated to 7-10 $\mathrm{ml}$ by sedimentary method for qualitative and quantitative measurement of phytoplankton. Also, to thicken phytoplankton, a vacuum filter (PVF-35/NB) was used for hydrobiological studies in water. To

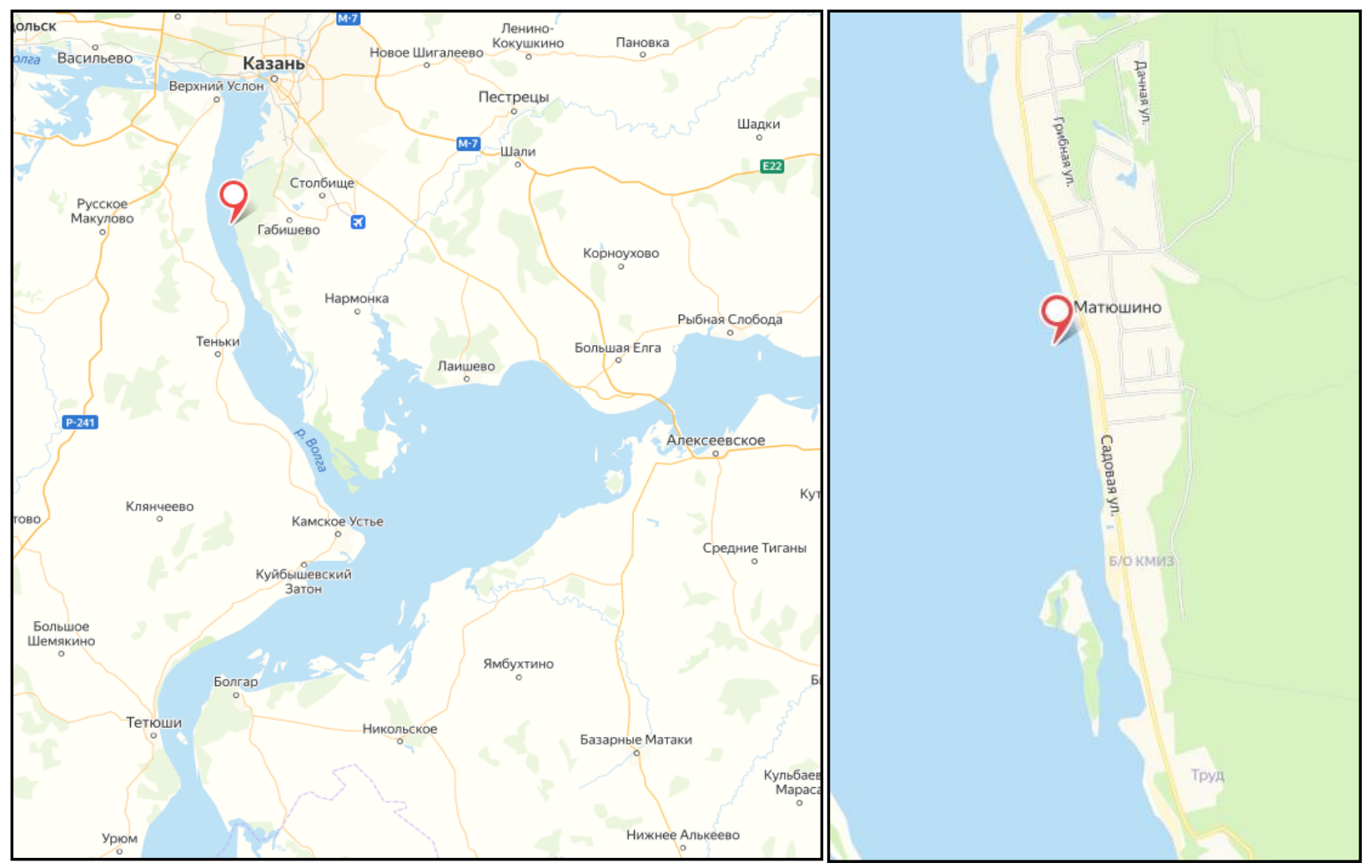

Figure 1 Location map of the phytoplankton study area of the Volga reach of the Kuibyshev Reservoir (Borovoe Matyushino, 2015).

Journal of Experimental Biology and Agricultural Sciences http://www.jebas.org 
concentrate the phytoplankton, Vladipor membrane filters (MFAS - OS - 2 and MFAS - OS - 3 type) with pore sizes of 0.45 and 0.8 $\mu \mathrm{m}$ were used. The organisms were counted according to the generally accepted method in the Goryaev chamber. The volumetric method was used to determine biomass. During the entire research period, meteorological conditions and hydrological features of the sampling area (water level, transparency, etc.) were also recorded.

\section{Results and Discussion}

\subsection{Composition and ecologically floristic characteristic of algae}

During the study, 112 taxa of planktonic algae were identified. The greatest diversity was found of ochrophytic algae (Table 1, Figure 2) and each sample contains 6 to 15 species in large quantities (Figure 3). Most often, the samples contained species of bluegreen, diatoms, green and dinophytic algae. Ecologically and geographically, most of the identified algae are cosmopolitan planktonic species and are indifferent with halobility; alkaliphilic + alkalibiontic species are most often indifferent with $\mathrm{pH}$. In terms of saprobity, $\beta$-mesosaprobic organisms predominate (Table 2).

\subsection{Seasonal changes in planktonic algae}

The total abundance and biomass of planktonic algae ranged 8.5$1661.1 \mathrm{mln} . c 1 . / 1$ and $10.3-114.1 \mathrm{mg} / \mathrm{l}$ respectively (Figure 4-8). Some common quantitatively dominating phytoplankton bluegreen algae are Microcystis aeruginosa f. flos-aquae (Wittr.) Elenk., Aphanizomenon flos-aquae (L.) Ralfs., Anabaena flosaquae Breb., Anabaena scheremetievi Elenc., Aulacoseira italica (Ehr.) Kiitz., Naviculasp. sp., Carteria globosa Korschik., Chlamydomonas sp., Pandorina morum (Mill.) Bory., Scenedesmus guadricauda (Turp.) Breb.

The seasonal dynamics of phytoplankton involved two peaks of abundance and biomass. Among these, the first peak fell on the border of the first and second decades of July (a week earlier than in the upstream areas) which might be due to the shallowness of this area, which warms up faster and has a slower flow. The second peak in time coincided with the "bloom" of water with blue-green algae throughout the reservoir and fell in the second decade of August. Both maxima are due to the massive development of bluegreen algae, which cause water bloom. The phytoplankton of the investigated section of the Kuibyshev reservoir is dominated by $\beta$ mesosaprobic organisms.

The objective of this study was to investigate the phytoplankton population in the water column, which was mainly represented by metaphyton. In the initial period of littoral community formation, dominating species were algae with a wide environmental range, capable to live within the plankton and benthos. These are mainly the species of filamentous centric and pennate diatoms, and
Table 1 Main systematic phytoplankton algal groups of the Volga reach of the Kuibyshev Reservoir (Borovoe Matyushino, 2015)

\begin{tabular}{|c|c|c|}
\hline Phylum & Class & Order \\
\hline \multirow{3}{*}{ Cyanophyta } & \multirow{3}{*}{ Cyanophyceae } & Chroococcales \\
\hline & & Oscillatoriales \\
\hline & & Nostocales \\
\hline Cryptophyta & Cryptophyceae & Cryptomonadales \\
\hline Dinophyta & Dinophyceae & Peridiniales \\
\hline \multirow{9}{*}{ Ochrophyta } & Chrysophyceae & Chromulinales \\
\hline & \multirow{8}{*}{ Bacillariophyceae } & Thalassiosirales \\
\hline & & Melosirales \\
\hline & & Aulacosirales \\
\hline & & Fragilariales \\
\hline & & Naviculales \\
\hline & & Achnanthales \\
\hline & & Cymbellales \\
\hline & & Surirellales \\
\hline \multirow{3}{*}{ Chlorophyta } & \multirow{3}{*}{ Chlorophyceae } & $\begin{array}{l}\text { Chlamydomonada } \\
\text { les }\end{array}$ \\
\hline & & Volvocales \\
\hline & & Sphaeropleales \\
\hline
\end{tabular}

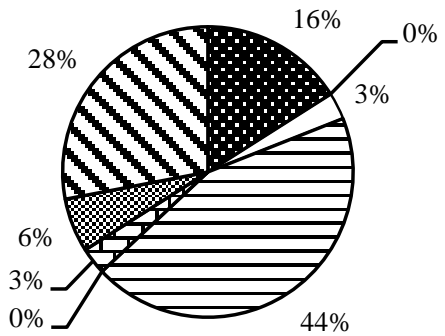

- Cyanophyta

口- Dinophyta

口- Bacillariophyta

口- Cryptophyta

Q - Chrysophyta

v- Chlorophyta

Figure 2 Distribution of the phytoplankton taxa at the Volga reach of the Kuibyshev Reservoir (Borovoe Matyushino, 2015)

chlorococcales. However, at the beginning of the water warming the macrophytes are joined by epipelon and epiphytic algae (large species having heteropolar structure of cells or colonies, often able to mobility). These are types of diatoms and blue-green algae, scraps of green filamentous and desmidia algae. During the observation period, 112 phytoplankton taxa were found at the study site. The greatest number of taxa were identified from the groups of diatoms (43.75\%) and green (28.13\%) algae. Some other less diverse groups are blue-green (15.63\%), Chrysophyta (6.25\%), cryptophyta, and dinophyta (3.13\%) each. Cosmopolitan and planktonic species of algae prevail in terms of environmental and 
number of species

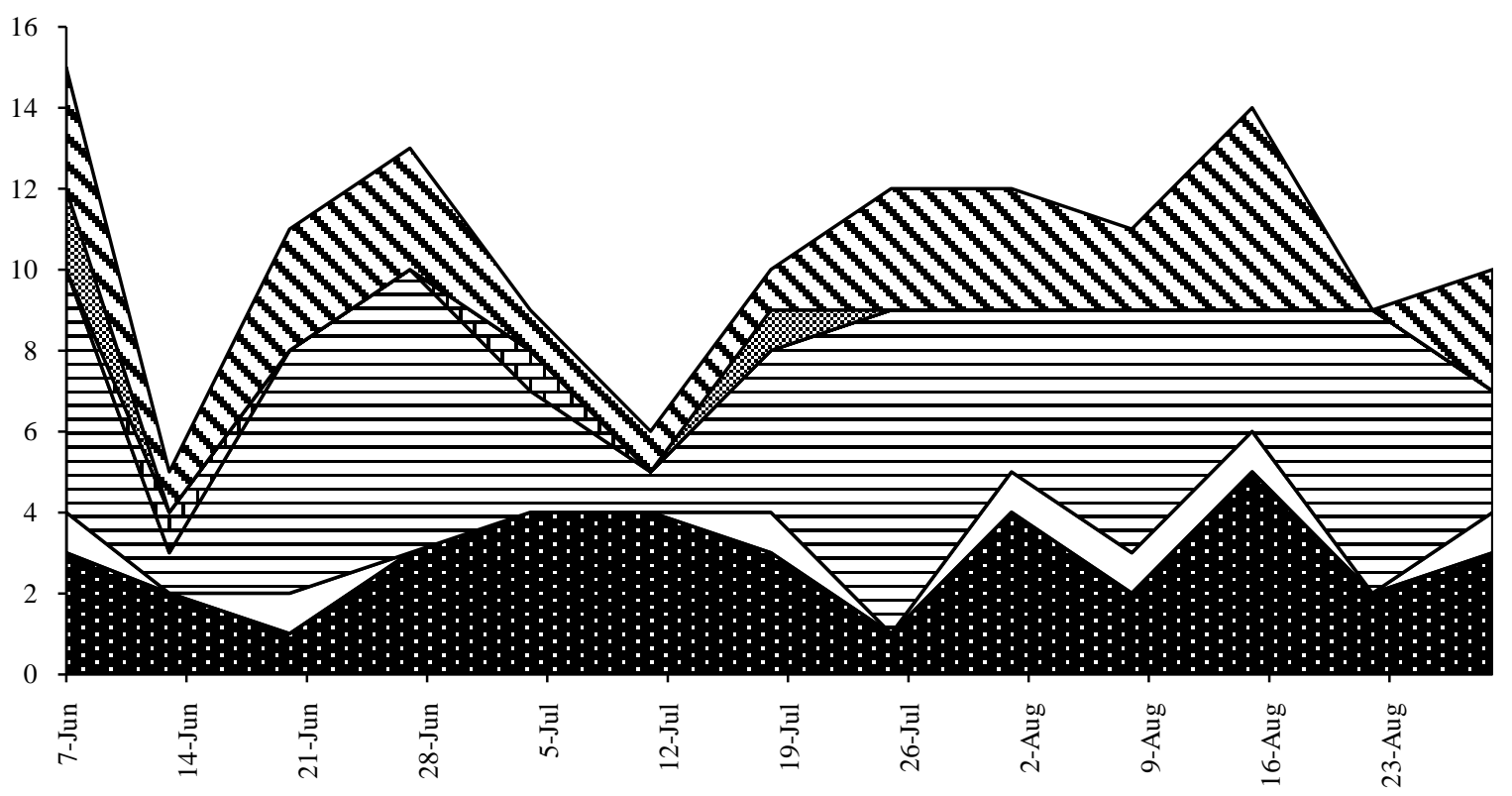

$\begin{array}{llll}\text { 国 Cyanophyta } & \square \text { Euglenophyta } & \square \text { Dinophyta } & \text { 目Bacillariophyta } \\ \text { 国Cryptophyta } & \mathbf{0} \text { Chrysophyta } & \mathbf{0} \text { Chlorophyta } & \end{array}$

Figure 3 Distribution of the phytoplankton taxa at the Volga reach of the Kuibyshev Reservoir (Borovoe Matyushino, 2015)

million cell / 1

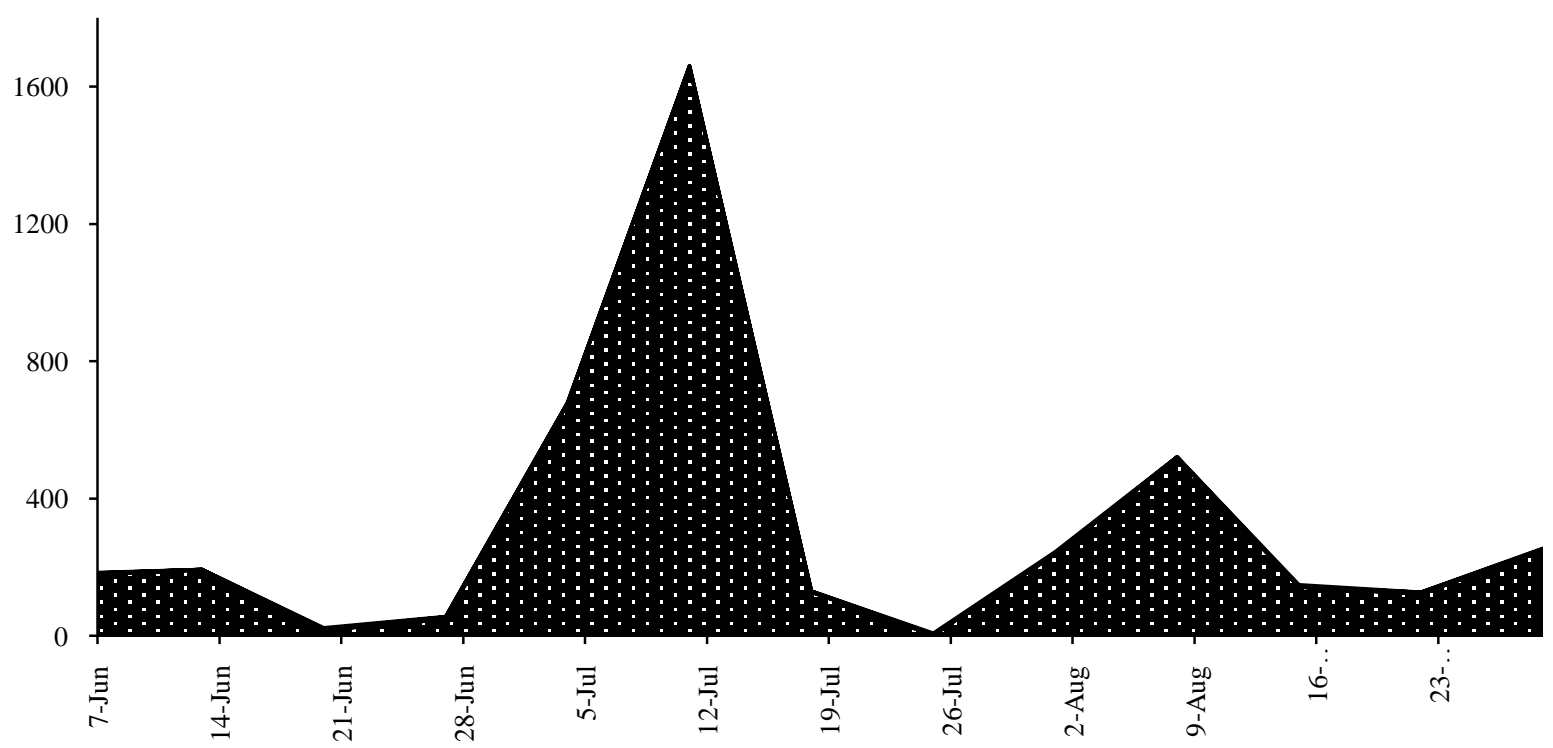

Figure 4 Seasonal dynamics of the abundance of blue-green planktonic algae (million cells/l) at the Volga reach of the Kuibyshev reservoir (Borovoe Matyushino, 2015)

Journal of Experimental Biology and Agricultural Sciences http://www.jebas.org 
Table 2 Ecologically and geographical characteristics of common species of phytoplankton of the Volga reach of the Kuibyshev Reservoir (BorovoeMatyushino, 2015)

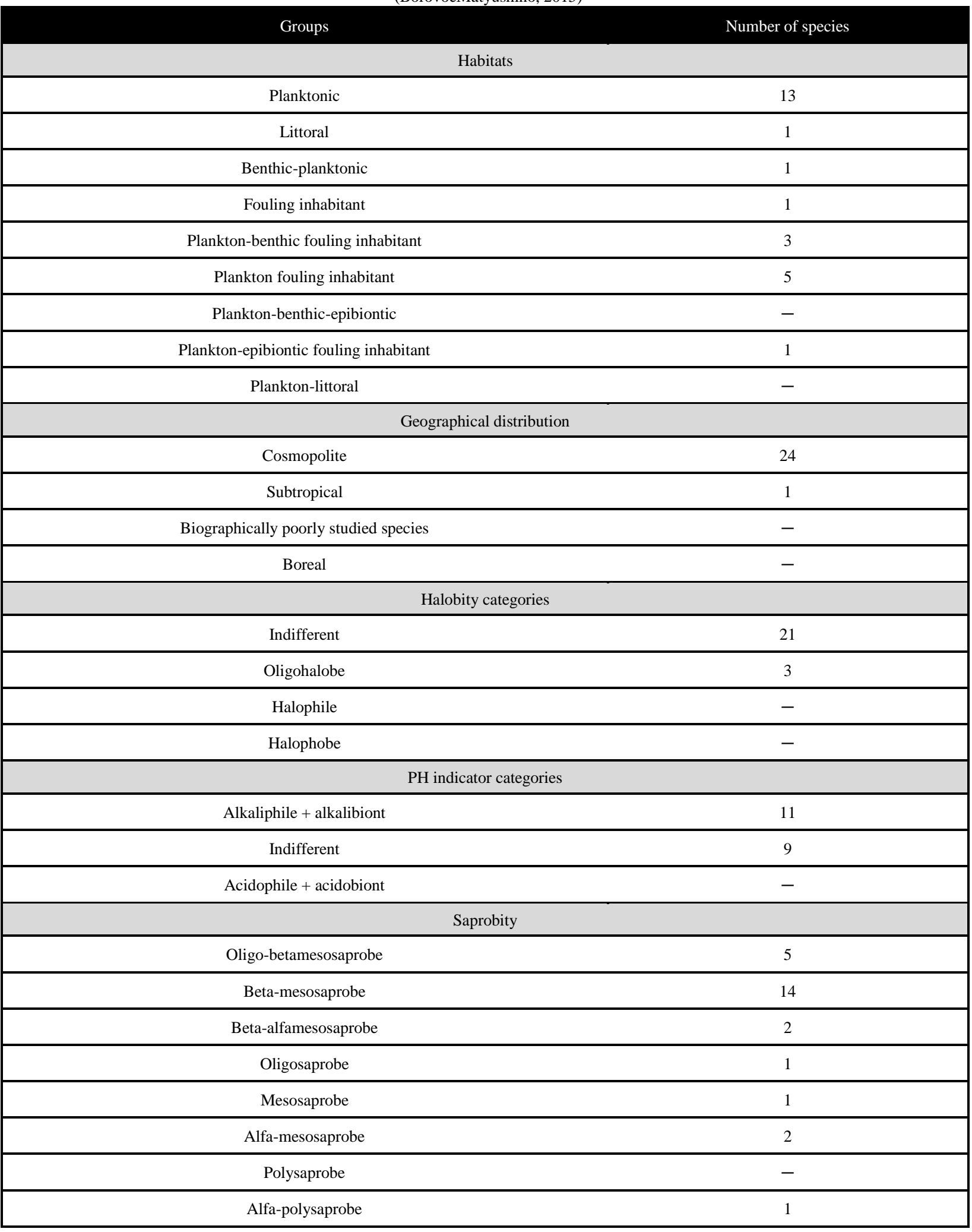


million cell / 1

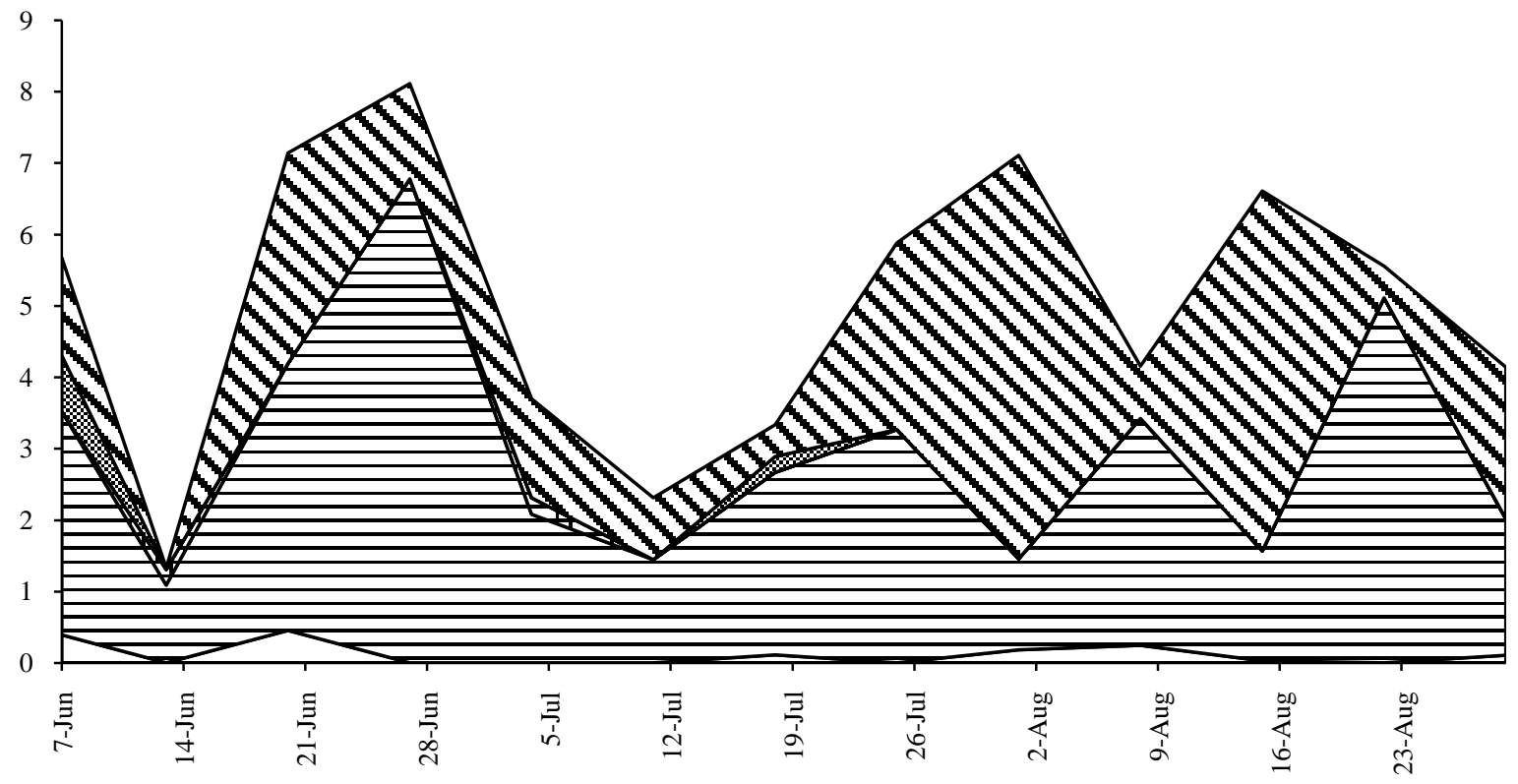

Figure 5 Seasonal dynamics of the abundance of dominanting planktonic species of algae (excluding blue-green algae ) (million cells/l) at the Volga reach of the Kuibyshev reservoir (Borovoe Matyushino, 2015)

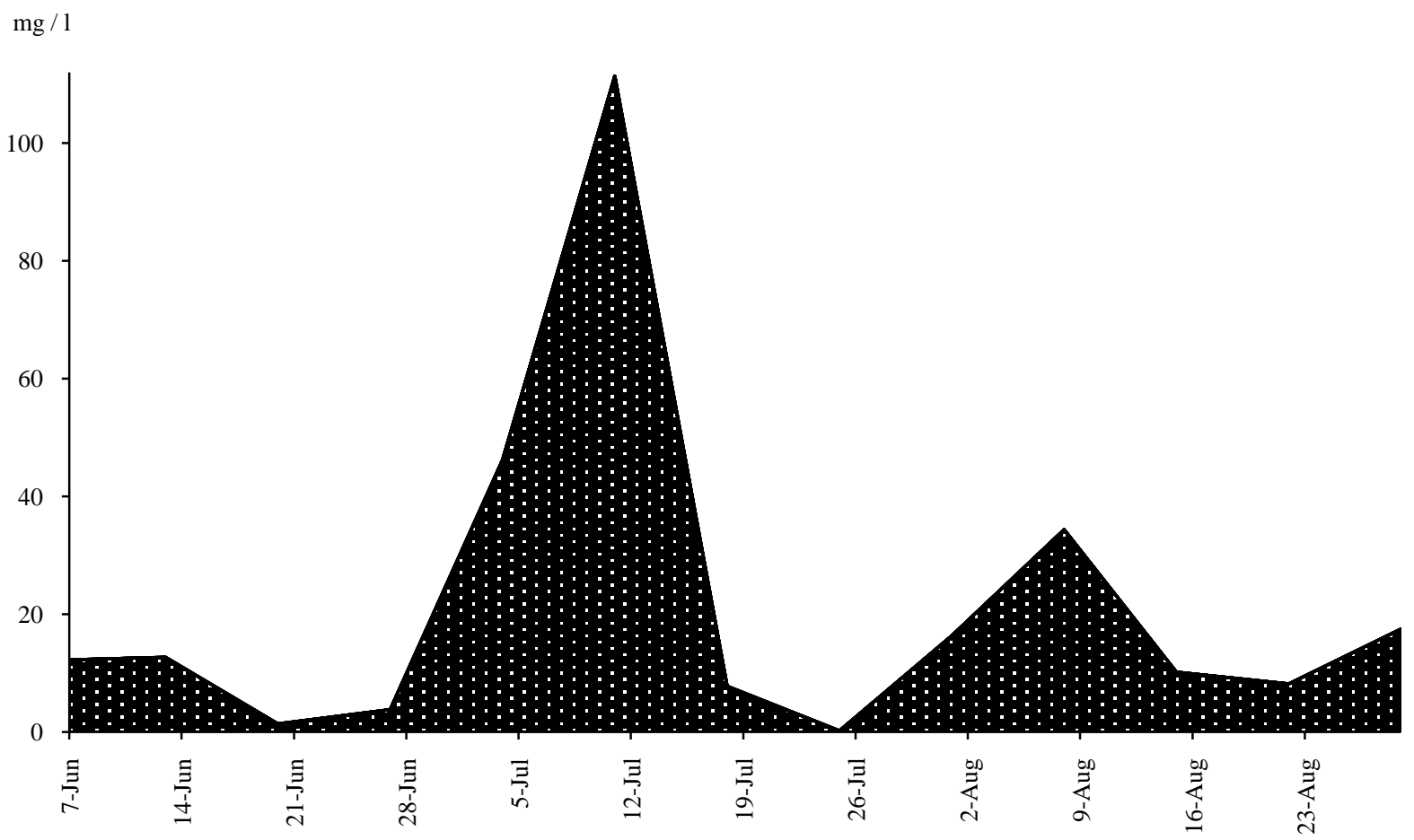

Figure 6 Seasonal dynamics of biomass (mg/l) of blue-green planktonic algae at the Volga reach of the Kuibyshev reservoir (Borovoe Matyushino, 2015)

Journal of Experimental Biology and Agricultural Sciences http://www.jebas.org 


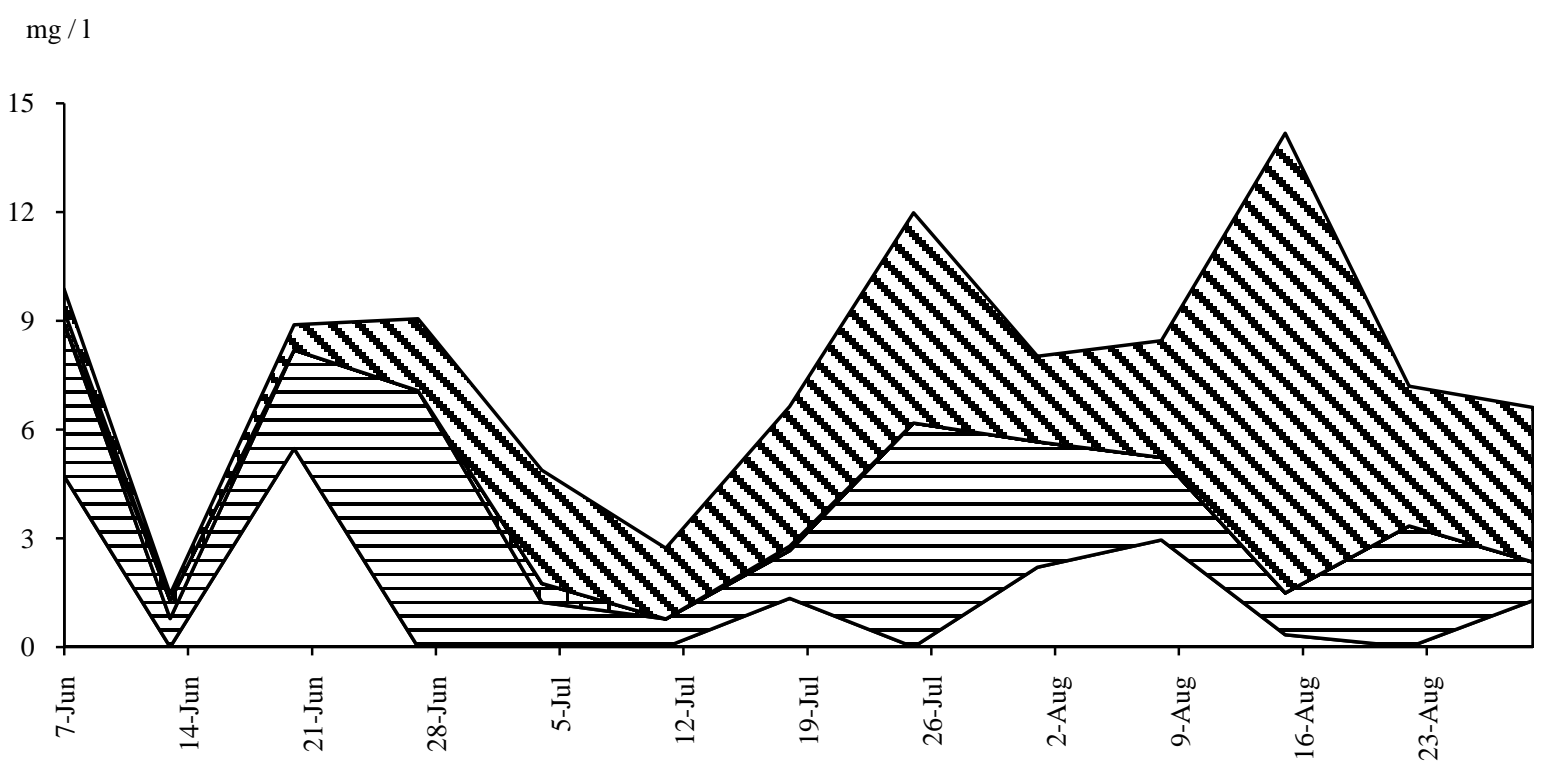

Figure 7 Seasonal dynamics of biomass ( $\mathrm{mg} / \mathrm{l})$ of the dominant species of planktonic algae (excluding blue-green algae) at the Volga reach of the Kuibyshev reservoir (Borovoe Matyushino, 2015)

million cell / 1

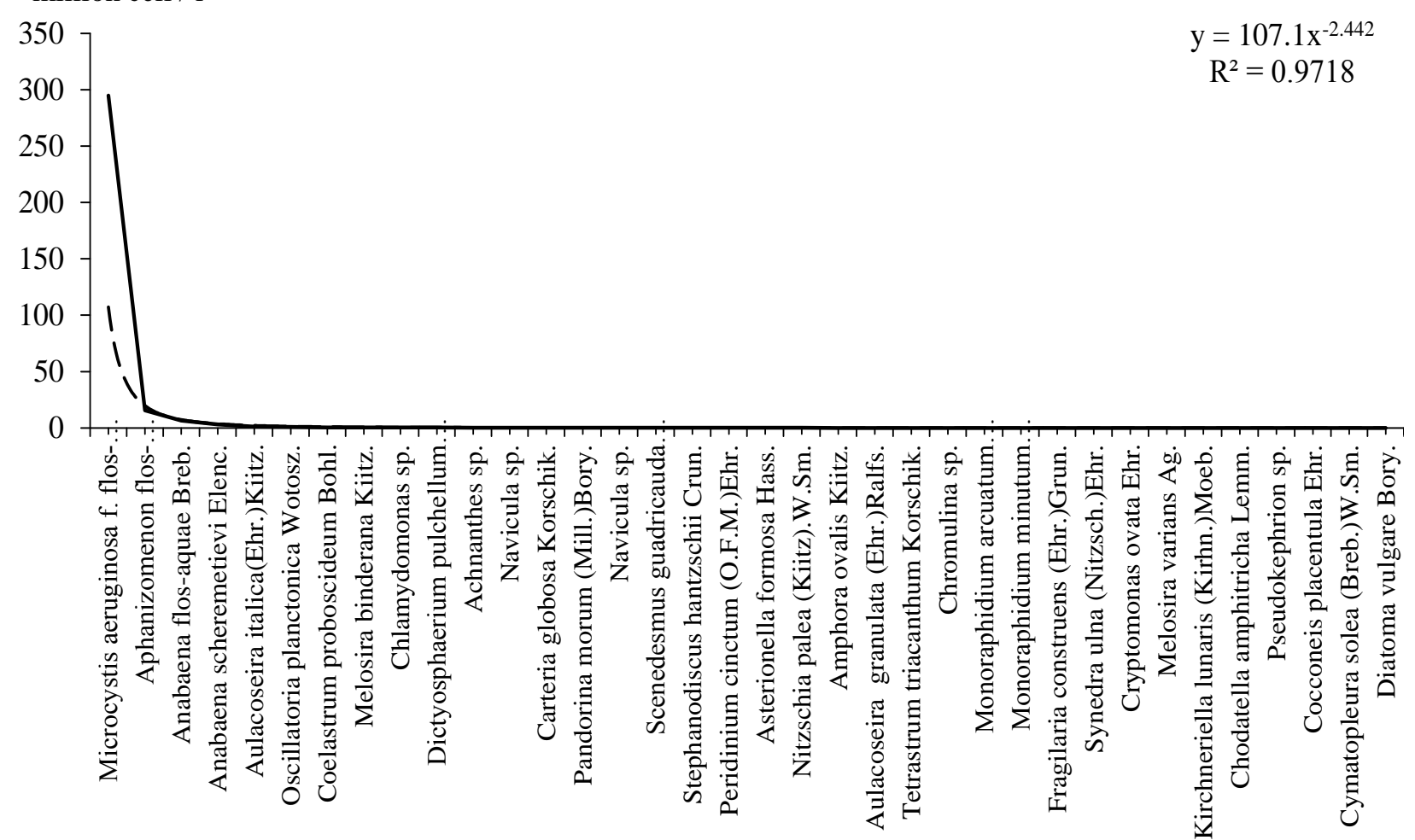

Figure 8 Distribution of the average abundance (million cells/l) of dominant species of planktonic algae (excluding blue-green algae) of the Volga reach of the Kuibyshev reservoir (Borovoe Matyushino, 2015) 
geographical characteristics. With halobility, most species are indifferent, and in terms of $\mathrm{pH}$, the most common species are the indifferent and alkaliphile + alkalibiontic algae.

\section{Conclusions}

Biocenosis of shallow waters live increased variability of habitat regimes and are characterized by a special structural and functional organization. To fully elucidate these features, it is necessary to research the Kuibyshev reservoir simultaneously in several hydrologically different areas. A comparison and analysis of the data will provide more reliable statistics. This article presents the results of studies of the Volga reach of the Kuibyshev reservoir near the left bank. The future works will present a comparative analysis of the phytoplankton structure of the left and right banks, as well as other areas of the middle part of the reservoir. This study was performed under the State Program of Competitive Growth of the Russian Federation at Kazan Federal University.

\section{Acknowledgments}

The work is performed according to the Russian Government Program of Competitive Growth of Kazan Federal University.

\section{Conflict Of Interest}

Authors would hereby like to declare that there is no conflict of interests that could possibly arise.

\section{References}

AlgaBase (2000) AlgaBase is a database of information on algae that includes terrestrial, marine and freshwater organisms. Available at http://algabase.org/ Accessed on 16.07.2020.

Algae (1989) Reference book. Kyiv: NaukovaDumka, P. 608.

Cantonati M (2017) Freshwater Bentic Diatoms of Central Europe:
Over 800 Common Species Used in Ecological Asessment. Berlin: Spektrum Akademischer Verlag,. 942 s. ISBN-13:978946538066.

Khaliullina LY, Khaliullin II, Yakovlev VA (2009) Seasonal and year-to-year dynamics of phytoplankton in connection with the level regime of the Kuibyshev reservoir. Water Resources 36(4): 459-465.

Korneva LG (2009) Formation of phytoplankton in water bodies of the Volga basin under the influence of natural and anthropogenic factors [Text]: author's abstract, Ph.D. Biology; IBVV RAS. St.P, - Pp. 47.

Krammer K (1991a) Bacillariophyceae. 3. Teil: Centrales, Fragilariaceae, Eunotiaceae. Susswasserflora von Mitteleuropa. Berlin: Spektrum Akademischer Verlag, Pp.576.

Krammer K (1991b) Bacillariophyceae. 4. Teil: Achnanthaceae, Kritische Erganzungen zu Navicula (Lineolatae) und Gomphonema. Susswasserflora von Mitteleuropa. Berlin: Spektrum Akademischer Verlag, Pp. 437.

Kuibyshev reservoir phytoplankton ecology. - L.: Nauka, 1989. - P. 304.

Kuibyshev reservoir (2008) (Scientific and Information Guidebook). - Togliatti: IEVB RAS, - p. 123.

Pröschold T, Leliaert F (2007) Systematics of the green algae: conflict of classic and modern approaches // Unravelling the algae. The past, present, and future of algal systematics. The Systematics Association Special 75: 123-153.

Sadchikov AP (2003) Methods of studying freshwater phytoplankton. - M.: "Universitet i Shkola", - Pp. 200

Stasenko AL (1997) Rotation: rivers, typhoons, molecules [Text]. Quant5: 30-31 